(C) Elsevier/INRA

Original article

\title{
Growth, carcass and meat quality performance of crossbred pigs with graded proportions of Meishan genes
}

\author{
JP Bidanel ${ }^{1 *}$, JC Caritez ${ }^{2}, \mathrm{~J}_{\text {Gruand }}{ }^{3}, \mathrm{C}_{\text {Legault }}{ }^{1}$ \\ 1 INRA, Station de Génétique Quantitative et Appliquée, \\ Centre de Recherches de Jouy-en-Josas, 78352 Jouy-en-Josas Cedex; \\ 2 INRA, Domaine Expérimental du Magneraud, $17 \% 00$ Surgères ; \\ 3 INRA, Station Expérimentale de Sélection Porcine, 86480 Rouillé, France
}

(Received 3 December 1991; accepted 18 September 1992)

Summary - Growth, carcass and meat quality traits were measured in 2 different experimental herds on male and female pigs produced from matings between Piétrain boars and 12 genetic types of sows with graded proportions of Large White (LW) and Meishan (MS) genes. Growth records (from 30-100 kg liveweight) were obtained on ad libitum feeding on a total of 1640 pigs, among which 1200 were submitted to carcass evaluation and meat quality measurements. Genetic type mean performance essentially varied according to the relative proportions of MS and LW genes in the dam and could hence be characterized by a single parameter, difference in crossbreeding $\left(\Delta_{M S-L W}^{c}\right)$, which measures the difference between MS and LW breeds used as dam breeds. Differences in crossbreeding were unfavourable to MS for all growth and carcass traits. Average estimates of $\Delta_{M S-L W}^{c}$ were $-71 \pm 16 \mathrm{~g} / \mathrm{d} ; 0.21 \pm 0.07 ;-2.4 \pm 0.3 \% ;-9.0 \pm 0.5 \%$ for average daily gain (ADG) feed conversion ratio, killing out percentage and estimated carcass lean content $(\% \mathrm{M})$, respectively. However, significant herd differences were observed for ADG and $\% \mathrm{M}$. The 2 herd estimates were $-51 \pm 16 \mathrm{~g} / \mathrm{d}$ and $-92 \pm 30 \mathrm{~g} / \mathrm{d}$ for ADG, $-7.3 \pm 0.6 \%$ and $-10.7 \pm 1.5 \%$, for $\% \mathrm{M}$. Conversely, differences in crossbreeding for meat quality traits were in favour of MS, with an advantage of $1.1 \pm 0.4$ point in meat quality index over LW, $i e$ one third of a phenotypic standard deviation.

pig / crossbreeding / Chinese breed / growth / carcass / meat quality

Résumé - Performances de croissance, de carcasse et de qualité de la viande de porcs comportant une proportion variable de gènes Meishan. Des performances de croissance, de carcasse et de qualité de la viande ont été mesurées dans 2 élevages expérimentaux sur des porcs mâles et femelles issus d'accouplements entre des verrats Piétrain et 12 types génétiques de femelles comportant des proportions variables de gènes Large White (LW)

\footnotetext{
* Correspondence and reprints
} 
et Meishan (MS). Le contrôle de croissance (de 30 à $100 \mathrm{~kg}$ de poids vif) a été réalisé en alimentation à volonté sur un total de 1640 porcs, dont 1200 ont fait l'objet d'une évaluation de la qualité de la carcasse et de la viande. Les performances moyennes des différents types génétiques varient essentiellement en fonction des proportions relatives de gènes $M S$ et $L W$ chez la mère et peuvent donc être caractérisées par un paramètre unique, la différence en croisement $\left(\Delta_{M S-L W}^{c}\right)$, qui mesure l'écart entre les races $M S$ et $L W$ utilisées comme mères des produits terminaux. Les différences en croisement sont en défaveur de la MS pour l'ensemble des caractères de croissance et de carcasse. Les estimations moyennes de $\Delta_{M S-L W}^{c} s$ 'élèvent $\grave{a}-71 \pm 16 \mathrm{~g} / \mathrm{j} ; 0,21 \pm 0,07 ;-2,4 \pm 0,2 \% ;-9,0 \pm 0,5 \%$ pour le gain moyen quotidien (GMQ), l'indice de consommation, le rendement et la teneur en muscle estimée (\%M) de la carcasse, respectivement. Cependant, des différences sigrificatives entre élevages sont observées pour $A D G$ et \%M. Les estimations des 2 élevages s'élèvent $\grave{a}-51 \pm 16 \mathrm{~g} / \mathrm{j}$ et $-92 \pm 30 \mathrm{~g} / \mathrm{j}$ pour $G M Q ;-7,3 \pm 0,6 \%$ et $-10,7 \pm 1,5$ pour $\% M$. $\grave{A}$ l'inverse, les différences en croisement pour les caractères de qualité de la viande sont en faveur de $M S$, avec un avantage de $1,1 \pm 0,4$ point d'indice de qualité de la viande sur $L W$, soit un tiers d'écart type phénotypique.

porcin / croisement / race chinoise / croissance / carcasse / qualité de la viande

\section{INTRODUCTION}

Some native porcine breeds from China, such as the Meishan lreed, exhibit exceptional reproductive ability compared to currently used maternal genotypes and could be of great value for improving sow productivity (Legault and Caritez, 1983). However, these Chinese breeds are also characterized by very poor growth and carcass performance (Legault et al, 1985). Hence, their economic value will largely depend on the relative economic contributions of productive and reproductive traits.

Several crossbreeding schemes can be implemented in order to take advantage of these extreme genotypes (Sellier and Legault, 1986; Bidanel, 1990). Their economic value can be assessed using the knowledge of a limited number of crossbreeding parameters (Dickerson, 1969, 1973; Hill, 1982). Accordingly, an experiment was designed to estimate crossbreeding parameters relative to the cross between one of these Chinese breeds, the Meishan, and the most widely used French breed, the Large White, for the main traits of economic interest. Estimates of crossbreeding parameters for sow productivity and growth traits have been reported by Bidanel et al, $(1989,1990)$ and Bidanel (1993). The purpose of the present study was to evaluate the growth, carcass and meat quality performance of crossbred pigs with various proportions of Meishan genes and estimate the relevant crossbreeding parameters. Piétrain boars were used as terminal sires.

\section{MATERIALS AND METHODS}

\section{Data and experimental design}

The data originate from a crossbreeding experiment between Large White (LW) and Meishan (MS) pig breeds which took place between 1983-1989 at the INRA experimental research farm of Le Magneraud (Surgères, Charente-Maritime, referred to 
as Le Magneraud). The 3-step design of the experiment was described in detail by Bidanel et al (1989). Briefly, the first step was a complete 2-breed diallel, which led to the production of 4 genetic types of females (MS, LW $\times$ MS, MS $\times \mathrm{LW}, \mathrm{LW}$ ) and 3 genetic types of males (MS, LW, $\mathrm{F}_{1}=\mathrm{LW} \times \mathrm{MS}$ or $\left.\mathrm{MS} \times \mathrm{LW}\right)$. In the second step, females chosen at random within each of the above-mentioned genotypes were mated to randomly chosen MS, LW and $F_{1}$ boars and produced 12 genetic types of litters. In the third step, randomly chosen females from these 12 genotypes were inseminated with semen from Piétrain boars in 5 successive parities. The data analysed in the present study include growth, carcass and meat quality performance of a random sample of the progeny of these females. The sow herd was managed under a batch farrowing system, with a 3-wk interval between contiguous batches. These batches then became postweaning and fattening batches of growing animals. The 12 genetic types of sows were not necessarily included in each batch. However, genetic types were allocated to batches so as to have a well connected design. Similar precautions were taken when allocating Piétrain boars to genetic types of sows. The pigs included in the present study were born between March 1986 and May 1988 in 29 different batches uniformly distributed over that period of time. One barrow and a minimum of 4 females per litter were randomly chosen at weaning. A total number of 1640 pigs were chosen. They were raised at Le Magneraud, with the exception of 2 batches, which were transferred to another INRA experimental farm located in Rouillé, Vienne. This farm will be referred to as Rouillé hereafter. Le Magneraud is a closed herd with a good sanitary status, whereas Rouille is an open herd and has a lower sanitary status. Buildings were closed in Le Magneraud and semi-open in Rouillé. The distribution of the 1640 pigs according to genetic type, herd and sex is presented in table I.

Table I. Distribution of pigs by genetic type, herd and sex.

\begin{tabular}{|c|c|c|c|c|c|}
\hline \multirow[t]{3}{*}{ Dam genetic type $e^{1}$} & \multirow{3}{*}{$\begin{array}{c}\text { No } \\
\text { of dams }\end{array}$} & \multicolumn{4}{|c|}{ No of animals } \\
\hline & & \multicolumn{2}{|c|}{ Le Magneraud } & \multicolumn{2}{|c|}{ Rouillé } \\
\hline & & Gilts & Barrows & Gilts & Barrows \\
\hline MS & 14 & 82 & 21 & 12 & 3 \\
\hline $\mathrm{MS}(\mathrm{LW} \times \mathrm{MS})$ & 12 & 78 & 20 & 30 & 9 \\
\hline $\mathrm{MS}(\mathrm{MS} \times \mathrm{LW})$ & 17 & 127 & 34 & 25 & 8 \\
\hline $\mathrm{F}_{1} \times \mathrm{MS}$ & 9 & 66 & 18 & 15 & 5 \\
\hline $\mathrm{LW} \times \mathrm{MS}$ & 10 & 109 & 37 & 13 & 2 \\
\hline $\mathrm{MS} \times \mathrm{LW}$ & 11 & 83 & 33 & 12 & 4 \\
\hline $\mathrm{F}_{1}(\mathrm{LW} \times \mathrm{MS})$ & 11 & 109 & 28 & 8 & 2 \\
\hline $\mathrm{F}_{1}(\mathrm{MS} \times \mathrm{LW})$ & 10 & 93 & 30 & 8 & 1 \\
\hline $\mathrm{F}_{1} \times \mathrm{LW}$ & 7 & 55 & 28 & 3 & 1 \\
\hline $\mathrm{LW}(\mathrm{LW} \times \mathrm{MS})$ & 9 & 68 & 22 & 12 & 1 \\
\hline $\mathrm{LW}(\mathrm{MS} \times \mathrm{LW})$ & 13 & 102 & 32 & 21 & 4 \\
\hline LW & 13 & 107 & 59 & - & - \\
\hline Total & 136 & 1079 & 362 & 159 & 40 \\
\hline
\end{tabular}

${ }^{1} \mathrm{LW}=$ Large White $; \mathrm{MS}=$ Meishan $; \mathrm{F}_{1}=\mathrm{LW} \times \mathrm{MS}$ or MS $\times \mathrm{LW}$. The sire breed is mentioned first. 


\section{Measurements}

Animals were transferred from the post-weaning building to the different fattening units $\approx 30 \mathrm{~kg}$ liveweight. They were penned in groups of 8-10, with ad libitum access to water and to a pelleted diet formulated to contain $3200 \mathrm{kcal}$ digestible energy $/ \mathrm{kg}$ and $16.5 \%$ crude protein. Each pen included animals from both sexes, but only one genetic type. Average daily gain and feed intake (on a pen basis) were measured from $30 \mathrm{~kg}$ liveweight to the day before slaughter.

Animals were slaughtered around $100 \mathrm{~kg}$ liveweight in a single slaughterhouse located $\approx 55 \mathrm{~km}$ from Le Magneraud and $35 \mathrm{~km}$ from Rouillé. A sub-sample of 1200 carcasses were cut for carcass and meat quality measurements. The day after slaughter, carcass weight, carcass length between the atlas and the anterior edge of the pulvian symphysis and backfat thickness at the levels of last lumbar vertebra (rump), last thoracic vertebra (back) and last cervical verterbra (neck) were measured. The right side of the carcass was weighed. This was considered the net half-carcass weight on which all subsequent calculations were based. They were then submitted to the standardized Paris-type cutting as described by Ollivier (1970). Muscle content of the carcass was estimated from the weight of 5 cuts, expressed as percentage of half carcass weight, according to the following equation (Pommeret and Naveau, 1979): percentage of muscle $=0.75+0.80$ (percentage of ham) +1.06 (percentage of loin) +0.48 (percentage of belly) -0.50 (percentage of backfat) -0.66 (percentage of leaf fat). Various meat quality criteria were also measured $24 \mathrm{~h}$ post mortem, including: 1) ultimate $\mathrm{pH}$ on longissimus dorsi, adductor femoris, gluteus superficialis and biceps femoris muscles; 2) water-holding capacity as assessed by the time (in tens of s) necessary for a piece of $\mathrm{pH}$ paper to get wet when put on the freshly cut surface of biceps femoris and gluteus superficialis muscles; and 3) reflectance of biceps femoris and gluteus superficialis muscles at $630 \mathrm{~nm}$, using a Manuflex reflectometer (scale 0 at 1000). A meat quality index (MQI), showing a within-slaughter day correlation of 0.72 with the technological yield of cooked Paris ham processing (Jacquet et al, 1984), was computed as follows: $\mathrm{MQI}=53.7+5.9019(\mathrm{pH}$ of adductor femoris muscle) +0.1734 (water holding capacity of biceps femoris muscle) -0.0092 (reflectance of biceps femoris muscle).

\section{Statistical analyses}

The data, with the exception of feed consumption and feed conversion ratio, were analysed using mixed model techniques (Henderson, 1984). When variances are known, best linear unbiased estimates of marginal means for main effects (averaged across appropriate interactions) and interactions can be obtained by solving mixed model equations. When variances are not known, as in the present case, they should be replaced by their restricted maximum likelihood estimates obtained from the data (Gianola et al, 1986). In the present study, dam $\left(\sigma_{d}^{2}\right)$ and litter $\left(\sigma_{l}^{2}\right)$ variances were estimated using Meyer's DFREML set of programs (Meyer, 1988, 1989). Estimation of fixed effects and hypothesis testing were then performed using the PEST computer package (Groeneveld and Kovac, 1990). 
The assumed model for growth and carcass traits was as follows:

$$
\begin{aligned}
y_{i j k l m n o p}=E_{i} & +B_{i j}+S_{k}+V_{l}+P_{m}+G_{n} \\
& +(E G)_{i n}+(S G)_{k m}+(P G)_{m n}+d_{n o}+l_{n o p}+c o v+e_{i j k l m n o p}
\end{aligned}
$$

where

$y_{i j k l m n o p}=$ an observable random variable;

$E_{i}=$ fixed effect of the $i$ th experimental herd $(i=1,2)$;

$B_{i j}=$ fixed effect of the $j$ th batch, nested within the $i$ th herd $(j=1,29)$;

$S_{k}=$ fixed effect of the $k$ th sex (females of barrows);

$V_{l}=$ fixed effect of the $l$ th artificial insemination sire $(l=1,25)$;

$P_{m}=$ fixed effect of the $m$ th parity of the dam $(m=1,5)$;

$G_{n}=$ fixed effect of the $n$th dam genetic type $(n=1,12)$;

$(E G)_{k n}=$ fixed effect of the interaction between the $i$ th herd and the $n$th genetic type;

$(S G)_{m n}=$ fixed effect of the interaction between the $k$ th sex and the $n$th genetic type;

$(P G)_{k m}=$ fixed effect of the interaction between the $m$ th parity of the dam and the $n$th genetic type; and

$d_{n o}=$ random effect of the oth dam, nested within the $n$th genetic type. The vector d of dam effects is $\mathbf{N}\left(\mathbf{0}, \mathbf{A} \sigma_{d}^{2}\right)$, where $\mathbf{A}=$ matrix of additive relationships between dams,

$l_{n o p}=$ random litter effect, nested within the oth dam and the $n$th genetic type. The vector $\mathbf{P}$ of litter effects is $\mathbf{N}\left(\mathbf{0}, \mathbf{I} \sigma_{l}^{2}\right)$, where $\mathbf{I}=$ identity matrix,

$c o v=$ covariable initial weight (for average daily gain) or final weight (for the other traits) and

$e_{i j k l m n o p}=$ residual effect. The vector e of residuals is $\mathbf{N}\left(\mathbf{0}, \mathbf{I} \sigma_{e}^{2}\right)$.

Preliminary analyses indicated that the covariable did not differ $(P>0.10)$ according to the genetic type.

A similar model was used for meat quality traits except that the batch effect was replaced by the effect of slaughter date. Feed intake and feed conversion ratio data were analysed using a fixed linear model including the effects of experimental herd, batch within herd, dam genetic type and the linear regressions on pen sex ratio and final weight.

The same models were used to estimate crossbreeding parameters, except that genetic type effects were replaced by their decomposition according to adequately parameterized crossbreeding parameters. Not all usual crossbreeding parameters (Dickerson, $1969 ; 1973$ ) could be estimated from the present set of data. It can be checked from table II that direct and maternal breed effects were confounded with $\mathrm{PI} \times \mathrm{MS}$ and $\mathrm{PI} \times \mathrm{LW}$ direct heterosis effects. This problem was solved by expressing genetic type means as a deviation from $\mathrm{PI} \times \mathrm{LW}$ mean $\mu_{P I \times L W}^{c}$ and by introducing a new parameter, difference in crossbreeding $\Delta_{M S-L W}^{c}$ (Bidanel, 1988). The expressions of $\mu_{P I \times L W}^{c}$ and $\Delta_{M S-L W}^{c}$ in terms of Dickerson's parameters are as follows:

$$
\begin{gathered}
\mu_{P I \times L W}^{c}=1 / 2 g_{P I}^{o}+1 / 2 g_{L W}^{o}+g_{L W}^{m}+g_{L W}^{n}+h_{P I \times L W}^{o} \\
\Delta_{M S-L W}^{c}=1 / 2\left(g_{M S}^{o}-g_{L W}^{o}\right)+\left(g_{M S}^{m}-g_{L W}^{m}\right)+\left(h_{P I \times M S}^{o}-h_{P I \times L W}^{o}\right)
\end{gathered}
$$


where: $g_{L W}^{o}, g_{M S}^{o}, g_{P I}^{o}=$ direct effects of LW, MS and PI breeds, respectively; $g_{L W}^{m}, g_{M S}^{m}=$ maternal effects of LW and MS breeds, respectively; $g_{L W}^{n}=$ grandmaternal effect of LW breed; $h_{P I \times M S}^{o}, h_{P I \times L W}^{o}=$ direct heterosis effects for PI $\times \mathrm{MS}$ and PI $\times L W$ crosses, respectively. It can be noticed that $\Delta_{M S-L W}^{c}$ also is the regression coefficient of performance on the percentage of MS genes.

Maternal epistatic recombination loss (Dickerson, 1969; 1973) was not included in final analyses because, as will be seen later, maternal non-additive effects were almost non-existent. The decomposition of the 12 genetic types according to reparameterized crossbreeding parameters is shown in table II.

\section{RESULTS}

\section{Analyses of variance}

Levels of significance of Fisher statistics for fixed effects are given in table III. A significant $(P<0.05)$ herd $\times$ genetic type interaction $(\mathrm{H} \times \mathrm{G})$ was observed for carcass composition, particularly adiposity traits. The sex $\times$ genetic type $(\mathrm{S} \times \mathrm{G})$ interaction was significant $(P<0.05)$ for average daily gain and killing out percentage. As will be seen later, these interactions were mainly due to herd or sex variations in breed differences. Parity $\times$ genetic type interactions $(P \times G)$ were also observed for average daily gain and various carcass traits. These $P \times G$ interactions generally had a rather complicated structure and were associated with relatively minor differences in genetic type effects. On the whole, examination of subclass means suggested that interactions did not result in rank changes of genetic types and did not preclude examination of genetic type, herd and sex as main effects.

Differences among herd and batches (or slaughter date) were highly significant for most growth, carcass and meat quality traits. Animals raised in Le Magneraud grew faster $(74 \pm 13 \mathrm{~g} / \mathrm{d})$, had a better feed conversion ratio $(-1.31 \pm 0.05)$, leaner carcasses $(-2.3 \pm 0.8 \mathrm{~mm}$ average backfat thickness) and a better meat quality $(2.50 \pm 0.4$ points of meat quality index). Conversely, they had a lower killing out percentage $(-1.1 \pm 0.3 \%)$ and shorter carcasses $(-17 \pm 5 \mathrm{~mm})$. The sire effect was highly significant for all growth and carcass traits. It also influenced ultimate $\mathrm{pH}$, but had no effect on reflectance and water holding capacity. Barrows grew faster $(35 \pm 6 \mathrm{~g} / \mathrm{d})$, had a higher killing out percentage $(0.5 \pm 0.2 \%)$ and better ultimate $\mathrm{pH}$ (from $0.03 \pm 0.01$ to $0.06 \pm 0.02$ according to the muscle) than gilts. On the other hand, females had leaner carcasses $(3.7 \pm 0.3$ points of estimated carcass lean percentage) and consumed less feed $(-0.25 \pm 0.07 \mathrm{~kg} / \mathrm{d})$ than castrates. Parity differences were significant for initial and final weights, age at $100 \mathrm{~kg}$ and backfat thickness. The major part of weight differences was present at the beginning of the test period. Weight increased from the first to the third parity, then decreased slightly. Conversely, backfat thickness increased from the first to the fifth parity.

The effect of genetic type was significant for all growth and carcass traits except final weight and shoulder weight. With very few exceptions, genetic types with equal percentages of MS genes had very similar performance. As a consequence, 5 aggregate genetic types could be defined: $1 / 2 \mathrm{MS}, 3 / 8 \mathrm{MS}, 1 / 4 \mathrm{MS}, 1 / 8 \mathrm{MS}$ and $1 / 2$ LW. For simplicity, only marginal means for these aggregate genotypes will 
Performance of crossbred Meishan pigs: production

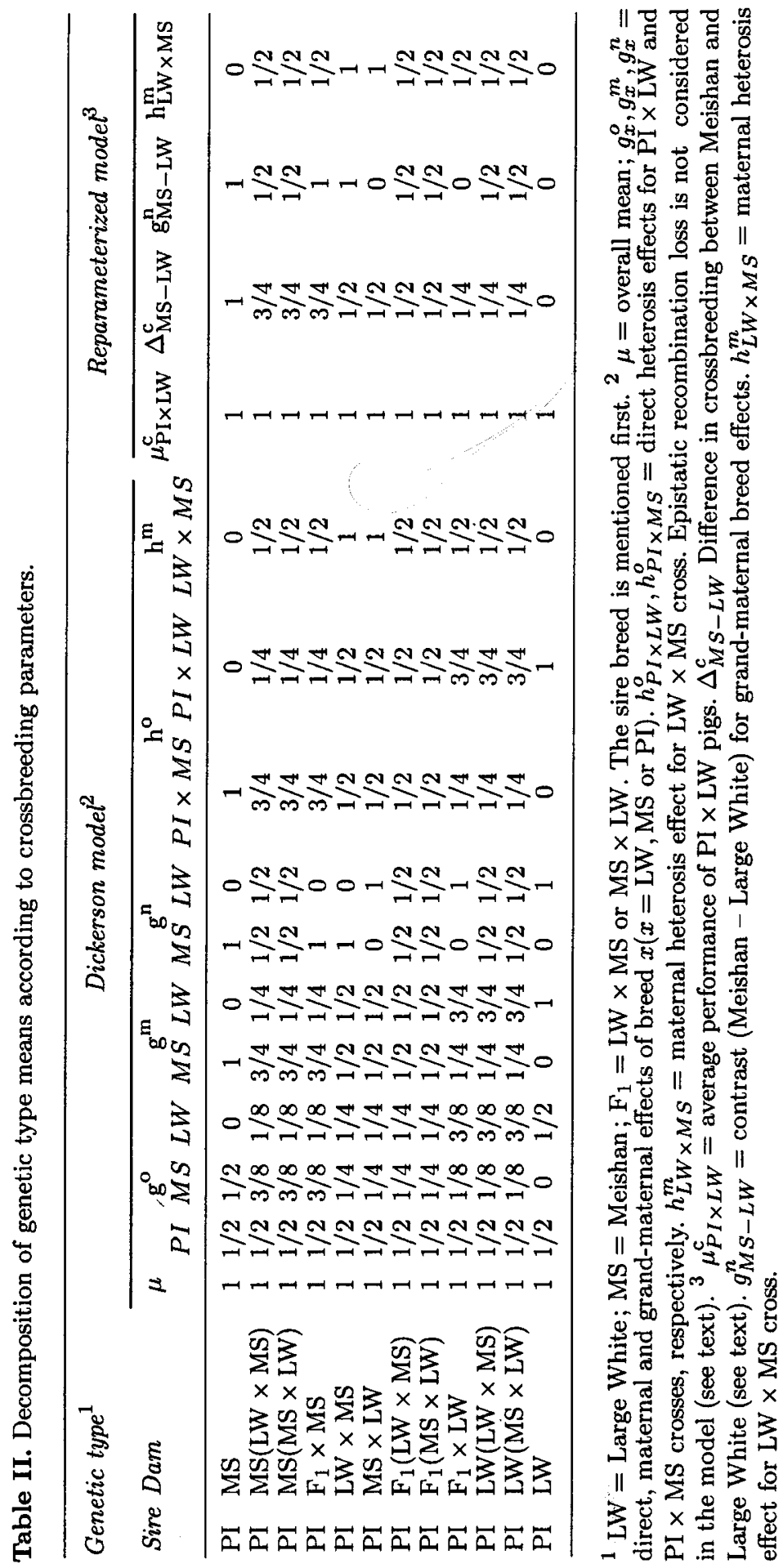




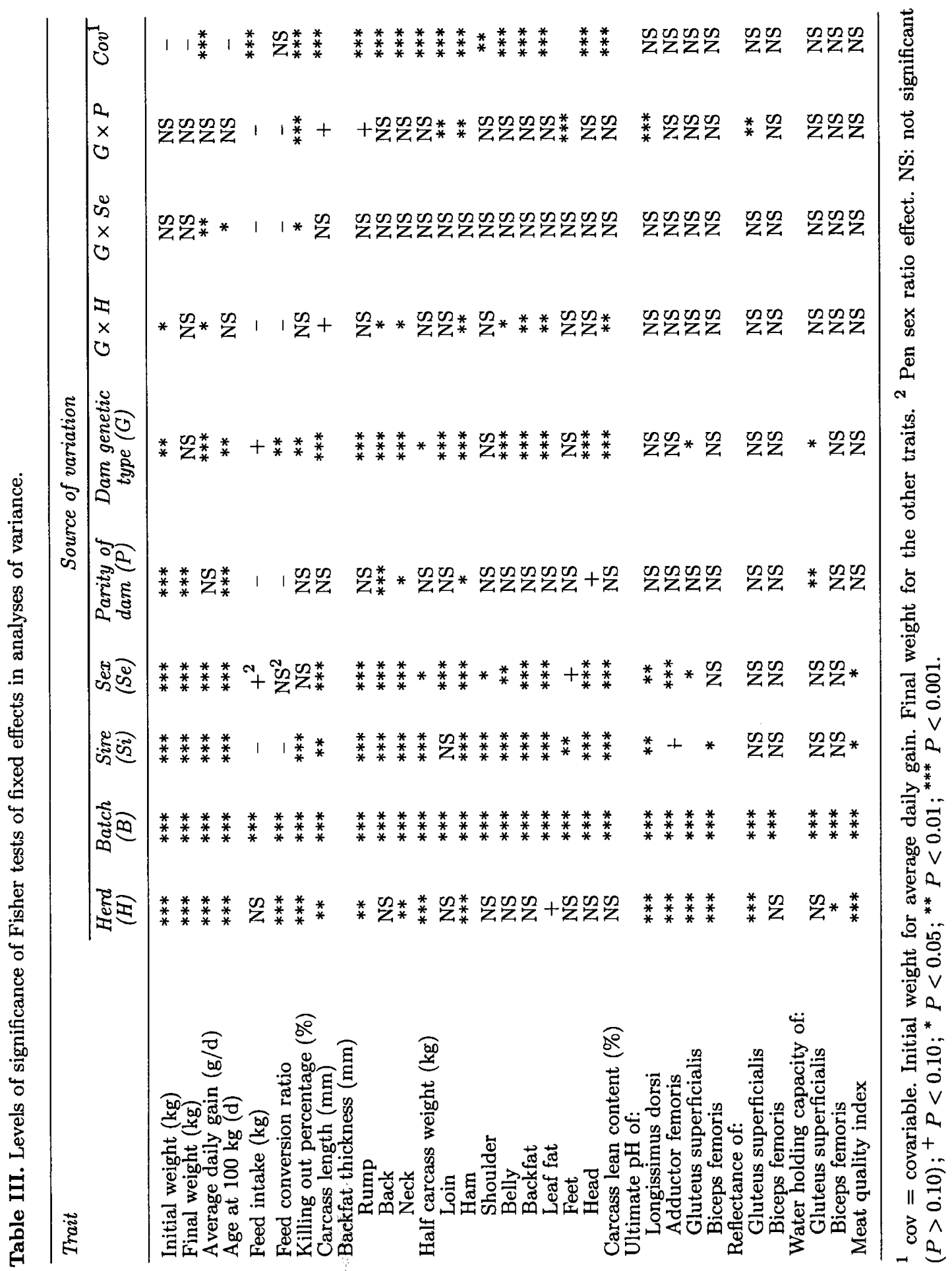


be presented. Marginal means for growth and carcass traits are shown in tables IV and $V$, respectively. Genetic types had very similar initial and final weights, except $1 / 2$ MS which were lighter $(P<0.05)$. Three groups could be defined with respect to growth rate. The $1 / 2 \mathrm{LW}$ and $1 / 8 \mathrm{MS}$ grew faster than $1 / 2 \mathrm{MS}$, with $3 / 8 \mathrm{MS}$ and $1 / 4 \mathrm{MS}$ being intermediate. Feed intake and feed conversion ratio were higher $(P<0.05)$ in MS and $3 / 4$ MS than the other genetic types. Variations in carcass performance were essentially related to the relative proportions of LW and MS genes. Increasing proportions of LW genes were associated with higher killing out percentages, longer carcasses, lower backfat thickness, larger lean cuts weights and lower fat cuts, feet and head weights. As a result, estimated carcass lean content of $1 / 2 \mathrm{MS}$ and $1 / 2 \mathrm{LW}$ pigs differed by 7.6 points of percentage (ie about $17 \%$ ).

Table IV. Estimates of genetic type marginal means for growth performance.

\begin{tabular}{llllllc}
\hline \multirow{2}{*}{ Trait } & \multicolumn{5}{c}{ Genetic type $^{1,2}$} & $\mathrm{SE}^{3}$ \\
\cline { 2 - 7 } & $1 / 2 M S$ & $3 / 8 M S$ & $1 / 4 M S$ & $1 / 8 M S$ & $1 / 2 L W$ & \\
\hline Initial weight (kg) & $28.8^{\mathrm{a}}$ & $30.0^{\mathrm{b}}$ & $30.0^{\mathrm{b}}$ & $29.4^{\mathrm{ab}}$ & $29.3^{\mathrm{b}}$ & $0.3-0.4$ \\
Final weight (kg) & $9^{\mathrm{a}}$ & $100.1^{\mathrm{b}}$ & $99.5^{\mathrm{b}}$ & $99.6^{\mathrm{b}}$ & $100.3^{\mathrm{b}}$ & $0.6-0.9$ \\
Average daily gain (g/d) & $696^{\mathrm{c}}$ & $736^{\mathrm{b}}$ & $738^{\mathrm{b}}$ & $767^{\mathrm{a}}$ & $777^{\mathrm{a}}$ & $8-14$ \\
Age at 100 kg (d) & $186^{\mathrm{c}}$ & $180^{\mathrm{b}}$ & $181^{\mathrm{b}}$ & $175^{\mathrm{a}}$ & $173^{\mathrm{a}}$ & $1-2$ \\
Feed intake (kg) & $2.31^{\mathrm{b}}$ & $2.31^{\mathrm{b}}$ & $2.23^{\mathrm{a}}$ & $2.24^{\mathrm{a}}$ & $2.24^{\mathrm{a}}$ & $0.03-0.06$ \\
Feed conversion ratio & $3.19^{\mathrm{b}}$ & $3.17^{\mathrm{b}}$ & $3.07^{\mathrm{a}}$ & $3.02^{\mathrm{a}}$ & $3.00^{\mathrm{a}}$ & $0.03-0.05$ \\
\hline
\end{tabular}

${ }^{1} \mathrm{LW}=$ Large White; MS = Meishan. ${ }^{2}$ Means with same letter do not differ at the $5 \%$ level. ${ }^{3}$ Standard error of marginal means.

Genetic type marginal means for meat quality traits are shown in table VI. Significant differences were observed for all traits except ultimate $\mathrm{pH}$ of adductor femoris, reflectance and water holding capacity of biceps femoris. As previously discussed, these differences were essentially due to the relative proportions of LW and MS genes. Increasing amounts of MS genes were associated with a higher ultimate $\mathrm{pH}$, a lower reflectance, a higher water holding capacity and, ultimately, a better meat quality index.

\section{Crossbreeding parameters}

Crossbreeding parameters for growth, carcass and meat quality traits are shown in tables VII, VIII and IX, respectively. Grand-maternal effects and maternal heterosis effects were significant for none of the traits. Hence, variations between genetic types were entirely due to differences in crossbreeding. MS genes led to a deterioration of growth rate $(-71 \pm 16 \mathrm{~g} / \mathrm{d})$. Yet, differences in average daily gain were much more important in barrows than in gilts $(-92 \pm 27 \mathrm{~g} / \mathrm{d} v s-51 \pm 16 \mathrm{~g} / \mathrm{d})$. A similar sex $\times$ genetic type interaction was observed for killing out percentage. The use of MS genes was associated with a larger decrease in killing out percentage in females than in males $(-2.8 \pm 0.3 v s-2.0 \pm 0.5$ percentage points). 
Table V. Estimates of genetic type marginal means for carcass traits.

\begin{tabular}{lcccccc}
\hline \multirow{2}{*}{ Trait } & \multicolumn{5}{c}{ Genetic type 1,2} & $S^{3}$ \\
\cline { 2 - 6 } & $1 / 2 M S$ & $3 / 8 M S$ & $1 / 4 M S$ & $1 / 8 M S$ & $1 / 2 L W$ & \\
\hline Killing out percentage (\%) & $79.5^{\mathrm{c}}$ & $80.3^{\mathrm{b}}$ & $80.6^{\mathrm{b}}$ & $81.0^{\mathrm{a}}$ & $81.5^{\mathrm{a}}$ & $0.2-0.4$ \\
Carcass length (mm) & $906^{\mathrm{c}}$ & $917^{\mathrm{bc}}$ & $928^{\mathrm{a}}$ & $926^{\mathrm{ab}}$ & $931^{\mathrm{a}}$ & $3-6$ \\
Backfat thickness (mm) & & & & & & \\
$\quad$ Rump & $23.2^{\mathrm{e}}$ & $20.6^{\mathrm{d}}$ & $18.5^{\mathrm{c}}$ & $17.2^{\mathrm{b}}$ & $15.5^{\mathrm{a}}$ & $0.5-0.8$ \\
Back & $27.0^{\mathrm{b}}$ & $25.6^{\mathrm{b}}$ & $23.1^{\mathrm{a}}$ & $22.7^{\mathrm{a}}$ & $21.8^{\mathrm{a}}$ & $0.5-0.8$ \\
Neck & $46.1^{\mathrm{c}}$ & $44.9^{\mathrm{c}}$ & $40.6^{\mathrm{b}}$ & $40.4^{\mathrm{ab}}$ & $39.1^{\mathrm{a}}$ & $0.6-1.0$ \\
Weight (kg) & & & & & & \\
Loin & $10.03^{\mathrm{e}}$ & $10.65^{\mathrm{d}}$ & $11.23^{\mathrm{c}}$ & $11.58^{\mathrm{b}}$ & $12.01^{\mathrm{c}}$ & $0.07-0.2$ \\
Ham & $8.55^{\mathrm{e}}$ & $8.96^{\mathrm{d}}$ & $9.32^{\mathrm{c}}$ & $9.64^{\mathrm{b}}$ & $9.88^{\mathrm{a}}$ & $0.05-0.08$ \\
Shoulder & $6.22^{\mathrm{a}}$ & $6.28^{\mathrm{a}}$ & $6.31^{\mathrm{a}}$ & $6.21^{\mathrm{a}}$ & $6.34^{\mathrm{a}}$ & $0.05-0.08$ \\
Belly & $4.52^{\mathrm{d}}$ & $4.35^{\mathrm{c}}$ & $4.17^{\mathrm{b}}$ & $4.11^{\mathrm{b}}$ & $3.99^{\mathrm{a}}$ & $0.04-0.06$ \\
Backfat & $4.72^{\mathrm{d}}$ & $4.34^{\mathrm{c}}$ & $3.83^{\mathrm{b}}$ & $3.78^{\mathrm{b}}$ & $3.48^{\mathrm{a}}$ & $0.07-0.12$ \\
Leaf fat & $0.84^{\mathrm{b}}$ & $0.80^{\mathrm{b}}$ & $0.63^{\mathrm{a}}$ & $0.61^{\mathrm{a}}$ & $0.59^{\mathrm{a}}$ & $0.02-0.03$ \\
Feet & $1.07^{\mathrm{c}}$ & $1.00^{\mathrm{b}}$ & $1.02^{\mathrm{b}}$ & $0.96^{\mathrm{a}}$ & $0.93^{\mathrm{a}}$ & $0.01-0.02$ \\
$\quad$ Head & $4.53^{\mathrm{c}}$ & $4.40^{\mathrm{c}}$ & $4.37^{\mathrm{b}}$ & $4.17^{\mathrm{a}}$ & $4.05^{\mathrm{a}}$ & $0.04-0.07$ \\
Estimated carcass lean & & & & & & \\
percentage (\%) & $45.5^{\mathrm{e}}$ & $47.9^{\mathrm{d}}$ & $51.0^{\mathrm{c}}$ & $52.1^{\mathrm{b}}$ & $53.8^{\mathrm{a}}$ & $0.3-0.5$ \\
\hline
\end{tabular}

${ }^{1} \mathrm{LW}=$ Large White MS $=$ Meishan. ${ }^{2}$ Means with same letter do not differ at the $5 \%$ level. ${ }^{3}$ Standard error of marginal means.

MS genes highly impaired carcass composition. For instance, mean differences in crossbreeding for average backfat thickness $(7.3 \pm 1.0 \mathrm{~mm})$ or estimated carcass lean content $(-9.0 \pm 0.5$ points of percentage) represented 4 and 3 within-breed phenotypic standard deviations, respectively. However, differences varied according to the herd. The disadvantage of MS over LW for backfat thickness was 2-3-fold larger in Rouillé than in Le Magneraud. A similar pattern was observed for ham, belly and fat cuts weights and, as a consequence, estimated carcass lean content (table VIII).

The use of MS genes led to an increase of ultimate $\mathrm{pH}$ of gluteus superficialis and biceps femoris muscles and, to a lower extent in the longissimus dorsi and adductor femoris muscles (table IX). MS genes also had a favourable effect on meat colour of the gluteus superficialis and biceps femoris muscles and on water holding capacity of the gluteus superficialis muscle. On the whole, meat quality index was improved by $1.1 \pm 0.4$ point, $i e \approx$ one third of the within-breed phenotypic standard deviation.

\section{DISCUSSION}

REML and BLUP techniques have seldom been used in the analysis of crossbreeding experiments, least-squares (LS) being the most widely used method. In fact, it may easily be shown that, for well designed experiments, using BLUP instead of LS leads to very few changes in point estimates of genetic types means or 
Table VI. Estimates of genetic type marginal means for meat quality traits.

\begin{tabular}{|c|c|c|c|c|c|c|}
\hline \multirow[t]{2}{*}{ Trait } & \multicolumn{5}{|c|}{ Genetic type $e^{1,2}$} & \multirow{2}{*}{$\mathrm{SE}^{3}$} \\
\hline & $1 / 2 M S$ & $3 / 8 M S$ & $1 / 4 M S$ & $1 / 8 M S$ & $1 / 2 L W$ & \\
\hline \multicolumn{7}{|l|}{ Ultimate pH of: } \\
\hline Longissimus dorsi & $5.68^{\mathrm{a}}$ & $5.64^{\mathrm{b}}$ & $5.61^{b}$ & $5.64^{\mathrm{b}}$ & $5.59^{\mathrm{b}}$ & $0.02-0.03$ \\
\hline Adductor femoris & $5.92^{\mathrm{a}}$ & $5.87^{\mathrm{ab}}$ & $5.84^{\mathrm{b}}$ & $5.83^{\mathrm{b}}$ & $5.87^{\mathrm{ab}}$ & $0.02-0.04$ \\
\hline Gluteus superficialis & $5.89^{\mathrm{a}}$ & $5.83^{\mathrm{ab}}$ & $5.80^{\mathrm{bc}}$ & $5.77^{\mathrm{cd}}$ & $5.73^{\mathrm{d}}$ & $0.02-0.03$ \\
\hline Biceps femoris & $5.82^{\mathrm{a}}$ & $5.76^{\mathrm{ab}}$ & $5.72^{\mathrm{bc}}$ & $5.71^{\mathrm{cd}}$ & $5.65^{\mathrm{d}}$ & $0.02-0.03$ \\
\hline \multicolumn{7}{|l|}{ Reflectance of ${ }^{4}:$} \\
\hline Gluteus superficialis & $313^{a}$ & $317^{\mathrm{a}}$ & $327^{\mathrm{ab}}$ & $333^{\mathrm{b}}$ & $329^{\mathrm{ab}}$ & $6-9$ \\
\hline Biceps femoris & $327^{\mathrm{a}}$ & $322^{\mathrm{a}}$ & $324^{\mathrm{a}}$ & $327^{\mathrm{a}}$ & $346^{\mathrm{b}}$ & $5-8$ \\
\hline \multicolumn{7}{|c|}{ Water holding capacity of ${ }^{5}$ : } \\
\hline Gluteus superficialis & $8.3^{\mathrm{a}}$ & $7.6^{\mathrm{ab}}$ & $6.5^{\mathrm{bc}}$ & $6.2^{\mathrm{c}}$ & $7.1^{\mathrm{abc}}$ & $0.5-0.8$ \\
\hline Biceps femoris & $12.0^{\mathrm{a}}$ & $12.1^{\mathrm{a}}$ & $11.9^{\mathrm{a}}$ & $12.3^{\mathrm{a}}$ & $11.7^{\mathrm{a}}$ & $0.5-0.8$ \\
\hline Meat quality index & $86.9^{\mathrm{a}}$ & $86.7^{\mathrm{a}}$ & $86.2^{\mathrm{b}}$ & $86.1^{\mathrm{b}}$ & $86.3^{\mathrm{ab}}$ & $0.2-0.4$ \\
\hline
\end{tabular}

${ }^{1} \mathrm{LW}=$ Large White $; \mathrm{MS}=$ Meishan. ${ }^{2}$ Means with same letter do not differ at the $5 \%$ level. ${ }^{3}$ Standard error of marginal means. ${ }^{4}$ Scale 0 to $1000 .{ }^{5}$ Scale 0 to 20 . Higher values denote better water holding capacity.

Table VII. Estimates of crossbreeding parameters ( \pm SE) for growth traits.

\begin{tabular}{|c|c|c|c|c|}
\hline \multicolumn{2}{|l|}{ Trait } & \multicolumn{3}{|c|}{ Parameter ${ }^{1}$} \\
\hline & & $\Delta_{\mathrm{MS}-\mathrm{LW}}^{\mathrm{c}}$ & $\mathbf{g}_{M S-L W}^{\mathbf{n}}$ & $\mathrm{h}_{\mathrm{LW} \times \mathrm{MS}}^{\mathrm{m}}$ \\
\hline \multirow[t]{5}{*}{ Average daily gain $(\mathrm{g} / \mathrm{d})$} & & $-71 \pm 16^{* * *}$ & $4 \pm 10$ & $-14 \pm 9$ \\
\hline & Males & $-92 \pm 27^{* * *}$ & & \\
\hline & Females & $-51 \pm 16^{* *}$ & & \\
\hline & $\mathrm{H}_{1} 2$ & $-54 \pm 16^{* * *}$ & & \\
\hline & $\mathrm{H}_{2}^{2}$ & $-89 \pm 30^{* *}$ & & \\
\hline \multirow[t]{3}{*}{ Age at $100 \mathrm{~kg}(\mathrm{~d})$} & & $8.5 \pm 2.5^{* *}$ & $-0.6 \pm 1.7$ & $0.2 \pm 1.6$ \\
\hline & Males & $10.7 \pm 4.4^{*}$ & & \\
\hline & Females & $6.3 \pm 2.5^{* * *}$ & & \\
\hline Feed intake $(\mathrm{kg})$ & & $0.07 \pm 0.06$ & $0.05 \pm 0.04$ & $-0.06 \pm 0.04$ \\
\hline Feed conversion ratio & & $0.21 \pm 0.07^{* *}$ & $0.05 \pm 0.05$ & $-0.03 \pm 0.05$ \\
\hline
\end{tabular}

${ }^{1} \Delta_{M S-L W}^{c}$ : difference (Meishan-Large White) in crossbreeding between Meishan and Large White breeds (see text); $g_{M S-L W}^{n}$ : contrast (Meishan-Large White) for grandmaternal effects; $h_{L W \times M S}^{m}$ : maternal heterosis effect; ${ }^{2} \mathrm{H}_{1}$ : Herd $1=$ Le Magneraud; $\mathrm{H}_{2}$ : Herd $2=$ Rouillé; ${ }^{*}: P<0.05 ;^{* *}: P<0.01 ;^{* * *}: P<0.001$.

crossbreeding parameters. Conversely, interval estimates are strongly affected. LS methods implicitly assume that individual records are independent. This is obviously not the case in most animal breeding situations. In the present case, both animals and dams were related. Ignoring these relationships leads to serious overestimation of the precision of genetic type means and crossbreeding parameters 
Table VIII. Estimates of crossbreeding parameters ( \pm standard error) for carcass traits.

\begin{tabular}{|c|c|c|c|}
\hline Trait & $\Delta_{\mathrm{MS}-\mathrm{LW}}^{\mathrm{c}}$ & Parameter ${ }^{1}$ & $\mathrm{~h}_{\mathrm{LW} \times \mathrm{MS}}^{\mathrm{M}}$ \\
\hline Killing out percentage (\%) & $-2.4 \pm 0.3^{* * *}$ & $0.3 \pm 0.3$ & $0.3 \pm 0.3$ \\
\hline Males & $-2.0 \pm 0.5^{* * *}$ & & \\
\hline Females & $-2.8 \pm 0.3^{* * *}$ & & \\
\hline Carcass length (mm) & $-10 \pm 6$ & $-5 \pm 5$ & $-2 \pm 5$ \\
\hline Backfat thickness (mm) & & & \\
\hline Rump & $6.9 \pm 0.9^{* * *}$ & $0.5 \pm 0.7$ & $-0.3 \pm 0.7$ \\
\hline Back & $\begin{array}{l}6.0 \pm 0.9^{* * *} \\
3.9 \pm 0.9^{* * *} \\
8.0 \pm 2.4^{* * *}\end{array}$ & $0.7 \pm 0.7$ & $-0.4 \pm 0.7$ \\
\hline Neck & $8.9 \pm 1.1^{* * *}$ & $0.7 \pm 0.8$ & $0.2 \pm 0.8$ \\
\hline $\begin{array}{l}\mathrm{H}_{1} \\
\mathrm{H}_{2}\end{array}$ & $\begin{array}{r}4.1 \pm 1.2^{* * *} \\
13.7 \pm 2.9^{* * *}\end{array}$ & & \\
\hline Loin & $-1.99 \pm 0.13^{* * *}$ & $0.05 \pm 0.10$ & $-0.05 \pm 0.10$ \\
\hline Ham & $-1.51 \pm 0.09 * * *$ & $0.13 \pm 0.07^{+}$ & $0.03 \pm 0.07$ \\
\hline $\mathrm{H}_{1}$ & $-1.24 \pm 0.10^{* * *}$ & & \\
\hline $\mathrm{H}_{2}$ & $-1.78 \pm 0.23^{* * *}$ & & \\
\hline Weight (kg) & & & \\
\hline Shoulder & $-0.01 \pm 0.08$ & $0.01 \pm 0.06$ & $-0.00 \pm 0.06$ \\
\hline Belly & $0.62 \pm 0.07 * * *$ & $-0.09 \pm 0.05^{+}$ & $0.01 \pm 0.05$ \\
\hline $\mathrm{H}_{1}$ & $0.37 \pm 0.07^{* * *}$ & & \\
\hline $\mathrm{H}_{2}$ & $0.88 \pm 0.17^{* * *}$ & & \\
\hline Leaf fat & $1.31 \pm 0.12^{* * *}$ & $0.06 \pm 0.09$ & $0.01 \pm 0.09$ \\
\hline $\mathrm{H}_{1}$ & $0.92 \pm 0.13^{* * *}$ & & \\
\hline $\mathrm{H}_{2}$ & $1.75 \pm 0.31^{* * *}$ & & \\
\hline Backfat & $0.33 \pm 0.04^{* * *}$ & $0.04 \pm 0.03$ & $-0.00 \pm 0.03$ \\
\hline $\mathrm{H}_{1}$ & $0.21 \pm 0.04^{* * *}$ & & \\
\hline $\mathrm{H}_{2}$ & $0.45 \pm 0.10^{* * *}$ & & \\
\hline Feet & $0.09 \pm 0.02^{* * *}$ & $0.02 \pm 0.02$ & $-0.01 \pm 0.02$ \\
\hline Head & $0.45 \pm 0.08^{* * *}$ & $0.04 \pm 0.06$ & $0.04 \pm 0.06$ \\
\hline Estimated carcass lean percentage (\%) & $-9.0 \pm 0.5^{* * *}$ & $-0.2 \pm 0.4$ & $0.0 \pm 0.4$ \\
\hline $\mathrm{H}_{1}$ & $-7.3 \pm 0.6^{* * *}$ & & \\
\hline $\mathrm{H}_{2}$ & $-10.7 \pm 1.3^{* * *}$ & & \\
\hline
\end{tabular}

${ }^{1} \Delta_{M S-L W}^{c}$ : difference (Meishan-Large White) in crossbreeding between Meishan and Large White breeds (see text); $g_{M S-L W}^{n}$ : contrast (Meishan-Large White) for grandmaternal effects; $h_{L W \times M S}^{m}$ : maternal heterosis effect for Meishan $\times$ Large White cross; ${ }^{2} \mathrm{H}_{1}$ : Herd $1=$ Le Magnereaud; $\mathrm{H}_{2}$ : Herd $2=$ Rouillé ${ }^{+}: p<0.10{ }^{* * *}: p<0.01$.

(Komender and Hoeschele, 1989). The main problem is then to know the variance components that should be used in the BLUP analysis. As shown by Gianola et al (1986), when variance components are not known, they should theoretically be replaced by their REML estimates. However, crossbreeding experiments often have a limited size, so that estimates of variance components have a limited precision. In the present case, approximate standard errors of $\sigma_{d}^{2} / \sigma_{p}^{2}\left(\sigma_{d}^{2}=\right.$ variance between dams; $\sigma_{p}^{2}=$ phenotypic variance) ranged between $0.06-0.09$. Yet, it 
Table IX. Estimates of crossbreeding parameters ( \pm standard error) for meat quality.

\begin{tabular}{|c|c|c|c|}
\hline Trait & $\Delta_{\mathrm{MS}-\mathrm{LW}}^{\mathrm{c}}$ & $\begin{array}{l}\text { arameter }^{1} \\
\mathbf{g}_{\mathrm{MS}-\mathrm{LW}}^{\mathbf{n}}\end{array}$ & $\mathrm{h}_{\mathrm{LW} \times \mathrm{MS}}^{\mathrm{M}}$ \\
\hline \multicolumn{4}{|l|}{ Ultimate pH of: } \\
\hline Longissimus dorsi & $0.07 \pm 0.04^{+}$ & $-0.01 \pm 0.03$ & $-0.02 \pm 0.03$ \\
\hline Adductor femoris & $0.05 \pm 0.05$ & $0.01 \pm 0.04$ & $-0.03 \pm 0.04$ \\
\hline Gluteus superficialis & $0.11 \pm 0.04^{* *}$ & $0.03 \pm 0.03$ & $-0.02 \pm 0.03$ \\
\hline Biceps femoris & $0.14 \pm 0.04^{* * *}$ & $0.01 \pm 0.03$ & $-0.01 \pm 0.03$ \\
\hline \multicolumn{4}{|l|}{ Reflectance of ${ }^{2}:$} \\
\hline Gluteus superficialis & $-27 \pm 10^{* *}$ & $4 \pm 7$ & $9 \pm 7$ \\
\hline Biceps femoris & $-19 \pm 9^{*}$ & $5 \pm 7$ & $-5 \pm 7$ \\
\hline \multicolumn{4}{|l|}{ Water holding capacity of ${ }^{3}$ : } \\
\hline Gluteus superficialis & $2.9 \pm 1.1^{* *}$ & $-0.9 \pm 0.8$ & $-1.6 \pm 0.8^{+}$ \\
\hline Biceps femoris & $-0.2 \pm 1.0$ & $0.2 \pm 0.8$ & $-0.3 \pm 0.8$ \\
\hline Meat quality index & $1.1 \pm 0.4^{* *}$ & $-0.3 \pm 0.3$ & $-0.3 \pm 0.3$ \\
\hline
\end{tabular}

${ }^{1} \Delta_{M S-L W}^{c}$ : difference (Meishan-Large White) in crossbreeding between Meishan and Large White breeds (see text) $g_{M S-L W}^{n}$ : contrast (Meishan-Large White) for grandmaternal effects; $h_{L W \times M S}^{m}$ : maternal heterosis effect for Meishan $\times$ Large White cross; ${ }^{2}$ scale $0-1000 ;{ }^{3}$ scale $0-20$. Higher values denote better water holding capacity; $+: P<0.10 ;{ }^{*}: P<0.05 ;^{* *}: p<0.01 ;^{* * *}: p<0.001$.

should be noted that the impact of variations in variance component ratios on estimates of crossbreeding parameters is far less important than the effect of ignoring relationships among animals (Komender and Hoeschele, 1989). Another potential source of bias comes from the fact that there is a priori little reason to assume a homogeneous variance - covariance structure among genetic types. If so, standard errors of marginal means would be either overestimated or underestimated according to the genetic type. Methods for testing the homogeneity of variances and estimating variance components in situations of heteroscedasticity in the field of animal breeding have recently been developed (Foulley et al, 1990; San Cristobal, 1992). In many situations such as the present one, investigations on this aspect are unfortunately limited by the small size of experimental designs. The impact of heterogeneous residual variances should be rather low, as: 1) differences are rather small; 2) it has been shown that, for rather balanced designs, estimates of fixed effects are rather robust against the effects of unequal residual variances (see for instance Kendall and Stuart, 1976, for a discussion). Conversely, the heteroscedasticity of genetic variances might be more important, particularly for interval estimates.

The validity of equations such as those used for estimating carcass lean content or meat quality index may also be questioned. Indeed, performance of extreme genotypes such as Chinese breeds may be outside the range of values used to establish these equations. This should not be the case for MQI, as differences between MS and LW in meat quality traits are rather limited. Conversely, average carcass lean content of genetic types such as 1/2 MS or 3/8 MS are in the lower 
range of values used by Pommeret and Naveau (1979). Hence, it is likely that the precision of estimated carcass lean content is a bit lower for $1 / 2 \mathrm{MS}$ or $3 / 8 \mathrm{MS}$ than for more standard ones such as $1 / 4 \mathrm{MS}, 1 / 8 \mathrm{MS}$ or $1 / 2 \mathrm{LW}$.

The results of the present study, referred to as study 3 hereafter, are rather consistent with those previously obtained by Legault et al (1985) on 1/4 MS pigs, referred to as study 1, and those of Guéblez et al (1987) on 1/4 MS and 1/8 MS pigs referred to as study 2 . In the 3 studies, the use of MS as a component of the maternal genotype led to a moderate decrease in growth rate (differences in crossbreeding $\Delta_{M S-L W}^{c}$ for average daily gain were $-56 \mathrm{~g} / \mathrm{d} ;-76 \mathrm{~g} / \mathrm{d}$ and $-52 \mathrm{~g} / \mathrm{d}$ in studies 1,2 and 3 , respectively), an important deterioration of carcass lean content $(-7 \%$, $-9.2 \%$ and $-9 \%$, respectively) and a small improvement of meat quality ( $1.0 \mathrm{pt}$, $0.4 \mathrm{pt}$ and $1.1 \mathrm{pt}$, respectively). Somewhat more variable results were observed for feed conversion ratio (FCR) and killing out percentage (KO\%). Differences in crossbreeding ranged from $0.10-0.46$ for FCR and from $0.8-2.5 \%$ for $\mathrm{KO} \%$. Large differences between animals issued from the same dam genetic type and sired by either Duroc or Meishan boars were also reported by Young (1992a, b). Meishansired pigs had a lower average daily gain $(-83 \mathrm{~g} / \mathrm{d} ; P<0.05)$, a higher feed conversion ratio $(+0.24 ; P<0.05)$, a larger backfat thickness $(+8.6 \mathrm{~mm} ; P<0.05)$ and a smaller longissimus muscle area $\left(-8.6 \mathrm{~cm}^{2} ; P<0.05\right)$ than Duroc-sired pigs.

As seen earlier, differences in crossbreeding $\Delta_{M S-L W}^{c}$ contain one-half of difference in direct breed effects, but also direct heterosis and maternal effects. Hence, breed differences cannot in general be estimated by extrapolating $\Delta_{M S-L W}^{c}$. Direct estimates of breed differences for growth rate and feed conversion ratio (Bonneau $e t$ al, 1990; D'Agaro et al, 1990; Bidanel et al, 1991; Yen et al, 1991) are much larger than those inferred from differences in crossbreeding, thus suggesting that maternal effects are important and/or that heterosis effects are larger in the MS $\times$ PI cross than in the MS $\times$ LW cross. Conversely, both types of estimates are similar for carcass and meat quality traits (for instance, the MS - LW difference for estimated carcass lean content was estimated as $-17.6 \%$ by Poilvet et al (1990) against $-18 \%$ in the present study). This is not unexpected, as carcass and meat quality traits are known to have an essentially additive inheritance.

Yet it must be remembered that the MS pigs used in this experiment originated from a very limited sample of animals. Hence, any extrapolation to the MS breed as a whole is unadvisable. Then, it should be kept in mind that animals were fed ad libitum with a relatively high energy diet. As already emphasized by Legault $e t$ al (1985), ad libitum feeding maximizes the expression of breed differences for body composition. Thus, it is likely that the disadvantage of MS over LW would have been lower under restricted feeding. Similarly, as shown by Bidanel et al(1991), the use of repartitioning agents such as pST would reduce MS - LW differences.

In any case, based on the results of present study and on the economic weights used for the evaluation of terminal products in France (Anonymous, 1990), ie $0.174 \mathrm{FF}$ per g average daily gain, $-109.95 \mathrm{FF}$ per point of feed conversion ratio, $4.48 \mathrm{FF}$ per point of meat quality index and $20 \mathrm{FF}$ (> $50 \%$ muscle) or $25 \mathrm{FF}$ $(<50 \%$ muscle) for carcass lean content, the reduction in gross margin per pig can be evaluated as 200,95 and $46 \mathrm{FF}$ in $1 / 2 \mathrm{MS}, 1 / 4 \mathrm{MS}$ and 1/8 MS, respectively, compared to $1 / 2 \mathrm{LW}$. Assuming a constant sow maintenance cost of $4000 \mathrm{FF}$ per year, individual piglet costs are reduced by $42 \mathrm{FF}, 56 \mathrm{FF}$ and $29 \mathrm{FF}$ in MS, 1/2 MS 
and 1/4 MS sows, respectively, compared to LW (Bidanel et al, 1989; Bidanel 1993). As a consequence, the economic balance clearly disfavours the use of MS pigs.

Yet, these assessments should be somewhat moderated due to the presence of genetic type $\times$ herd interactions in growth rate and carcass composition. Such interactions were not evidenced in the study of Legault et al (1985), but this first study involved a much smaller number of pigs. There are numerous reports of genotype $\times$ environment interaction in growth and carcass traits in swine (see for instance Davey et al, 1969). However, they mainly concern genetic type $\times$ feeding regime interactions. This was not the case in the present study, as feeding regimes were the same in both herds. The difference in the sanitary level of the 2 herds might be another possible explanation for this genotype $\times$ environment interaction. Slowly growing genetic types are more likely to be exposed to degraded sanitary conditions at the end of the test period. Such an interaction was also noticed by Kennedy and Quinton (1987).

In any case, this interaction will lead to large variations in the gross margin disadvantage of crossbred Chinese pigs $(80,40$ and $20 \mathrm{FF}$ per animal, respectively, for $1 / 2 \mathrm{MS}, 1 / 4 \mathrm{MS}$ and $1 / 8 \mathrm{MS}$ slaughter pigs). However, even in the best situation, the economic balance remains clearly unfavourable to the MS breed.

\section{CONCLUSION}

The present study confirms the important disadvantage of crossbred Meishan pigs with respect to currently used genetic types for growth and carcass traits. This disadvantage can noticeably differ according to the herd. However, simple economic evaluations clearly show that there is no short-term interest for using the Meishan breed under intensive production systems in France. Things might change in the future. Due to its exceptional reproductive performance, higher selection intensities, shorter generations intervals and consequently higher genetic gains can reasonably be expected from selecting a pure or a composite Meishan line, provided that genetic parameters are not unfavourable. The economic value of such strategies remains to be evaluated. This should be achieved using more realistic economic models than that used in the present study. Such models should in particular account for variations in the production and maintenance costs of sows and of the culling price of animals at the different levels of the crossbreeding system.

\section{REFERENCES}

Anonymous (1990) Résultat du $16^{\mathrm{e}}$ test d'évaluation des performances de croissance, de composition corporelle et de qualité de la viande des produits terminaux des schémas de sélection et de croisement. Techni-Porc 13, 29-46.

Bidanel JP (1988) Bases zootechniques et génétiques de l'utilisation en élevage intensif des races profiliques chinoises - cas du porc Meishan. Doctoral Thesis, Institut National Agronomique Paris-Grignon, France, p 194

Bidanel JP (1990) Potential use of prolific Chinese breeds in maternal lines of pigs. In: 4th World Congress on Genetics Applied to Livestock Production. Edinburgh, UK, vol $15,481-484$ 
Bidanel JP (1993) Estimation of crossbreeding parameters between Large White and Meishan porcine breeds. III. Dominance and epistatic components of heterosis on reproductive traits. Genet Sel Evol 25 (in press)

Bidanel JP, Caritez JC, Legault C (1989) Estimation of crossbreeding parameters between Large White and Meishan porcine breeds. I. Reproductive performance. Genet Sel Evol 21, 507-526

Bidanel JP, Caritez JC, Legault C (1990) Estimation of crossbreeding parameters between Large White and Meishan porcine breeds. II. Growth before weaning and growth of females during the growing and reproductive periods. Genet Sel Evol 22, 431-445

Bidanel JP, Bonneau M, Pointillart A, Gruand J, Mourot J, Demade I (1991) Effects of exogenous porcine somatotropin ( $\mathrm{pST}$ ) administration on growth performance, carcass traits, and pork meat quality of Meishan, Pietrain and crossbred gilts. $J$ Anim Sci 69, 3511-3522

Bonneau M, Mourot J, Noblet J, Lefaucheur L, Bidanel JP (1990) Tissue development in Meishan pigs: muscle and fat development and metabolism and growth regulation by somatotropic hormones: In: Chinese Pig Symposium (Molénat M, Legault C, eds) July 5-6 1990, Toulouse, France, 199-213

D'Agaro E, Haley CS, Ellis M (1990) Breed and genetic effects for pre- and post weaning performance in Large White and Meishan pigs and their reciprocal crosses. In: 4th World Congress on Genetics applied to Livestock Production. Edinburgh, $\mathrm{UK}$, vol 15, 485-488

Davey RJ, Morgan DP, Kincaid CM (1969) Response of swine selected for high and low fatness to a difference in dietary energy intake. J Anim Sci 46, 992-1000

Dickerson GE (1969) Experimental approaches in utilising breed resources. Anim Breed Abstr 37, 191-202

Dickerson GE (1973) Inbreeding and heterosis in animals. In: Proceedings of the Animal Breeding and Genetics Symposium in Honor of Dr JL Lush. Am Soc Anim Sci Dairy Sci Assoc, Champaign, IL, 54-77

Foulley JL, Gianola D, San Cristobal M, Im S (1990) A method for assessing extend and sources of heterogeneity of residual variances in mixed linear models. $J$ Dairy Sci 73, 1612-1624

Gianola D, Foulley JL, Fernando RL (1986) Prediction of breeding values when variances are not known. Génét Sél Evol 18, 475-484

Groeneveld E, Kovac M (1990) A generalized computing procedure for setting up and solving mixed linear models. J Dairy Sci 73: 513-531

Guéblez R, Bruel L, Legault C (1987) Evaluation des croisements sino-européens en conditions de terrain en France: bilan général. In: $19^{e}$ Journées de la Recherche Porcine en France. Paris, 4-5 February, 1987, Institut Technique du Porc, Paris, 25-32

Henderson CR (1984) Applications of linear models in animal breeding. Univ of Guelph, Guelph, Ontario, Canada.

Hill WG (1982) Dominance and epistasis as components of heterosis. Z Tierzüchtg Züchtgsbiol 99, 161-168

Jacquet B, Sellier P, Runavot JP, Brault D, Houix Y, Perrocheau C, Gogué J, Boulard J (1984) Prédiction du rendement technologique de la fabrication du 
"Jambon de Paris" à l'aide de mesures prises à l'abattoir. In: $16^{e}$ Journées de la Recherche Porcine en France. Paris, 1-3 February 1984, Institut Technique du Porc, Paris, 49-58

Kendall MG, Stuart AS (1976) The Advanced Theory of Statistics. Griffin, London, vol 3, 3rd edn

Kennedy BW, Quinton M (1987) A note on the effects of health environment on heterosis for growth rate in pigs. Anim Prod 44, 443-445

Komender P, Hoeschele I (1989) Use of mixed-model methodology to improve estimation of crossbreeding parameters. Livest Prod Sci 21, 101-113

Legault C, Caritez JC (1983) L'expérimentation sur le porc chinois en France. I. Performances de reproduction en race pure et en croisement. Génét Sél Evol 15, 225-240

Legault C, Sellier P, Caritez JC, Dando P, Gruand J (1985) Expérimentation sur le porc chinois en France. II. Performances de production en croisement avec les races européennes. Génét Sél Evol 17, 133-152

Meyer K (1988) DFREML a set of programs to estimate variance components under an individual animal model. J Dairy Sci 71, suppl 2, 33-34 (abstr)

Meyer K (1989) Restricted maximum likelihood to estimate variance components for animal models with several random effects using a derivative-free algorithm. Genet Sel Evol 21, 317-340

Ollivier L (1970) L'épreuve de la descendance chez le porc Large White français de 1953 à 1966. I. Analyse de la variation. Ann Génét Sél Anim 2, 311-324

Poilvet D, Bonneau M, Caritez JC, Legault C (1990) Carcass tissue composition in Meishan (MS), Large White (LW) and $\mathrm{F}_{1}(\mathrm{MS} \times \mathrm{LW})$ pigs. In: Chinese Pig Symposium (Molénat M, Legault C, eds) July 5-6, 1990, Toulouse, France, 237-238 Pommeret P, Naveau J (1979) Composition Anatomique de la Carcasse: la Découpe Parisienne Normalisée ( $D P N)$. Inst Tech Porc, Centre Exp Sél Porc Maxent, Rapp 79-06, 14 p ronéotypées

San Cristobal M (1992) Méthodes d'inférence statistique en modélisation de la variance. Application en génétique quantitative. Doctoral Thesis, Université Paul Sabatier de Toulouse, France, 228 p

Sellier P, Legault C (1986) The Chinese prolific breeds of pigs: examples of extreme genetic stocks. In: Exploiting new Technologies in Animal Breeding: Genetic Development (Smith C, King JWB, Mc Kay JC, eds) Oxford Univ Press, 153-162

Yen JT, Nienaber JA, Klindt J, Crouse JD (1991) Effect of ractopamine on growth, carcass traits, and fasting heat production of US contemporary crossbred and Chinese Meishan pure- and crossbred pigs. J Anim Sci 69, 4810-4822

Young LD (1992a) Effects of Duroc, Meishan, Fengjing, and Minzhu boars on productivity of mates and growth of first-cross progeny. J Anim Sci 70, 2020-2029 Young LD (1992b) Effects of Duroc, Meishan, Fengjing, and Minzhu boars on carcass traits of first-cross barrows. J Anim Sci 70, 2030-2037 